\title{
»Det er svært at tro på, at man ikke kan forbedre sig«. Potentialer og dilemmaer i udvikling af professionel underviserkompetence
}

Lone Krogh, PUC, Aalborg Universitet.

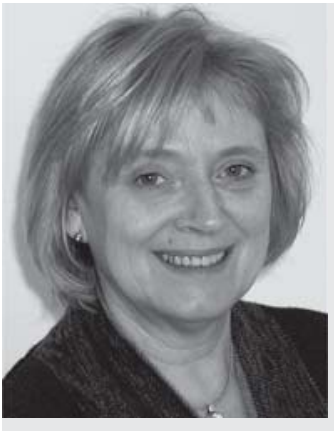

Lone Krogh er studielektor og leder af den universitetspædagogiske enhed (PUC) ved Aalborg Universitet, som er tværfakultær og placeret i tilknytning til Institut for Uddannelse, Læring og Filosofi. Har de seneste 10 år især beskæftiget sig med aktiviteter rettet mod udvikling af uddannelser og underviserkvalificeringsforløb ved Aalborg Universitet. Har løbende dokumenteret erfaringerne hermed i bøger og tidsskrifter. Har sideløbende med arbejdet ved universitetet udviklet og gennemført lærerkvalificeringsaktiviteter indenfor CVUområdet, erhvervsskoleområdet, gymnasieområdet og i forbindelse med efteruddannelse af læger.

Er uddannet cand.scient. adm. og socionom og har gennem de seneste 15 år forsket i og videreuddannet sig inden for det pædagogiske, didaktiske og læringsmæssige felt. Har tidligere undervist ved Det Samfundsvidenskabelige Fakultet på Aalborg Universitet og var fra 1987 - 1996 ansat i hhv. Arbejdsmarkedsstyrelsen og Danmarks Erhvervspædagogiske Læreruddannelse. Har herudover erfaringer fra sundhedssektoren. www.puc.aau.dk

Artiklen har afsat $i$ betingelser og vilkår for udvikling og organisering af universitetspeedagogisk efteruddannelse. Aktuelle samfundsmoessige og uddannelsespolitiske udviklingstendenser diskuteres som centrale vilkär for universiteterne og underviserne. Der er tale om betingelser og vilkär, som også har betydning for mange underviseres måde at forholde sig til padagogisk efteruddannelse på. Adjunktpadagogikum ved Aalborg Universitet beskrives som eksempel på, hvorledes udviklingen og undervisernes vilkår kan indtonkes $i$ organiseringen og struktureringen af adjunktpcedagogikum sammen med nyere viden om undervisnings- og laringsteori.
Artiklen skitserer undervejs en række problemstillinger, som har betydning for dagligdagen ved landets universiteter. Artiklen er normativ og diskuterende og dermed ikke umiddelbart kritisk i forhold til samfundsmæssige udviklingstendenser og konsekvenser for vilkårene for undervisningen, selvom der kunne være gode grunde til at råbe »vagt i gevær«. Formålet med den er at synliggøre kompleksiteten i udviklingen og give et bud på, hvorledes krav om mere professionalitet i undervisningen kan håndteres via et kvalificeringsforløb, hvor den komplicerede kontekst er medtænkt som et grundvilkår.

\section{You'll have a hard time believing} you cannot improve

"When I started the PUC course I had the feeling that the teachers couldn't teach me anything useful since I've already been a (good, if you ask me:-) teacher within the university for 7-8 years. Furthermore I was myself a student not too long ago - so how difficult could it be.... One might even say I was a bit arrogant towards this course.

And I was right. They couldn't teach me anything!!

Why? Because (as I learned on the course) teachers cannot teach a student anything. They can only create a situation where the student has the possibility to learn IF he/she is capable and motivated. In other words, the only one that can teach me anything is me!

Therefore I would probably have ended up learning nothing new if it hasn't been for the study-group.

At first we were all a bit defensive in the group. But as time passed and we read some literature we all started to realize that our own teaching style could easily be improved. This led to vivid discussions on our past experiences, why we did as we did and what we have learned. In other words we started REFLECTING. For me this was excellent. I became aware 
of why I was teaching as I was, what was good about it and what could/should be improved. I think those of us in the group who put a "piece of our self" into the discussions all learned a great deal and are better teachers today (and know why!). Those who didn't might as well have stayed at home or done something else...

My conclusions and recommendations:

1) the course is good if you're motivated

2) the study-group is excellent for discussions and reflections if and only if you are motivated and willing to open up and recognize pros and cons of your own teaching style

3) for the first time you have all the knowledge, support (from literature, peers, supervisors) and time needed to prepare a lecture like you always dreamt about ...

4) try to capture one of your lectures on video and see all of it (2x45min). You'll then have a hard time believing you cannot improve«.

Udtalelsen er fra en lektor med naturvidenskabelig baggrund, der gennemførte adjunktpædagogikum for få år siden og som nu er fag-pædagogisk vejleder for engelsktalende adjunkter. Hans udtalelse faldt i forbindelse med start af et nyt adjunktpædagogikumforløb, bestående af bl.a. adjunkter fra lande i Europa og Mellemamerika. Den illustrer på mange måder, hvordan adjunkter oplever det at skulle deltage i universitetspædagogisk efteruddannelse. For det første, hvorfor deltage i et kursus for at lære at undervise, når man allerede oplever sig selv som en ganske dreven underviser, både med erfaring som underviser og fra egen deltagelse i et utal af uddannelses- og undervisningsforløb. Der er tale om en holdning, som kendetegner mange veluddannedes tilgang til deltagelse i efteruddannelse (Argyris, 1991). For det andet, hvis ikke motivationen er til stede, ja, så er læringsudbyttet tvivlsomt. For nogles vedkommende kommer motivationen aldrig. I dette tilfælde var det læsning af teori og diskussioner i studiegruppen, tid til at arbejde med undervisningen samt supervision og videooptagelser af undervisningen, der var afgørende for oplevelsen af et læringsudbytte. Udtalelsen illustrerer således også den positive historie. Sidst i artiklen kommer jeg ind på de pædagogiske principper i adjunktpædagogikum ved Aalborg Universitet, som søger at imødekomme nogle af de problematiske vilkår, adjunkterne oplever, men som også peger på muligheder for, at der for nogle adjunkters vedkommende oparbejdes motivation for at arbejde med undervisning og vejledning.

Udfordringerne i håndteringen af universitetspædagogiske kvalificeringsforløb er mangeartede. For det første ansættes universitetsundervisere først og fremmest på baggrund af deres forskningsmæssige meritter og vil derfor primært lægge vægt på fortsat at kvalificere sig inden for forskningsfeltet. For det andet er der tale om meget veluddannede mennesker, der selv via egne uddannelser har deltaget i mange forskellige undervisningssituationer og for nogles vedkommende allerede har mange undervisningserfaringer. Nogle er oveni købet allerede ganske dygtige og erfarne undervisere, - i hvert fald set $\mathrm{i}$ lyset af mere traditionelle opfattelser af uddannelse og undervisning fra især forelæsninger og kursusundervisning. Dvs. rent undervisningsteknisk fungerer undervisningen ofte $\mathrm{OK}$ for nogle, mens andre måske har lært at acceptere den frustration, der kan være $i$ at opleve, at ens undervisning ikke altid fungerer efter hensigten. For det tredje opleves adjunktperioden af mange som en presset periode, netop fordi de skal kvalificere sig på så mange fronter med henblik på videre karriere $\mathrm{i}$ universitetssystemet.

Igennem de seneste årtier er der imidlertid kommet stadig mere samfundsmæssig fokus på bl.a. laringsmossige effekter af universitetsundervisning. Det er et fokus, der understøttes af nationale og internationale evalueringer, bl.a fra Danmarks Evalueringsinstitut og fra OECD. Nogle af anbefalingerne i OECD-evalueringen fra 2004 relaterer sig direkte til undervisningen, nemlig 1) Projektorienteret læring bør styrkes, 2) Nyansatte forskere og undervisere bør uddannes $i$ at undervise. 3) Universiteter bør udvikle mere engagerende undervisning. 4) Universiteter bør oprette enheder, der fremmer høj kvalitet i undervisningen, indfører nye undervisningsmetoder og styrker undervisernes pædagogiske evner.

På Aalborg Universitet har man siden 1994 arbejdet med en bevidst strategi for pædagogisk og didaktisk kvalificering af universitetets undervisere. Ét væsentligt initiativ var etableringen af Pædagogisk Udviklingscenter, hvor et af kerneområderne er Adjunktpædagogikum. Omkring 300 adjunkter har siden 1995 gennemført dette forløb. Hertil kommer et stort antal af andre universitetsansatte, der har deltaget i grundkurser, workshops, udviklings- og evalueringsprojekter. Det har betydet, at mange af de ansatte $\mathrm{i}$ dag har et vist teoretisk grundlag for at beskrive og tilrettelægge uddannelser og designe undervisningsforløb med afsæt i fagdidaktisk og pædagogisk tænkning.

Min tilgang til artiklens emne er afledt af min funktion som udvikler, underviser og kursusansvarlig ved en universitetspædagogisk enhed, hvor opgaven er ret klart defineret, nemlig at synliggøre og medvirke til at kvalitetssikre- og udvikle uddannelserne og undervisningen ved universitet. Det betyder, at jeg må forholde mig åbent til aktuelle udviklingstendenser på uddannelsesområdet, som kan få afgørende betydning for undervisningens vilkår og funktioner fremover og i samarbejde med kolleger vælge hensigtsmæssige strategier og implementeringsformer, for at imødekomme disse udviklingstendenser. Den udvikling, som vi aktuelt ser foregå i Danmark, kan på mange måder sammenlignes med den udvikling, der igennem flere år har foregået $i$ andre lande, hvor der ved flere universiteter er års erfaringer med at udarbejde strategier for udvikling og forbedring af uddannelserne og undervisningen. England er et af de lande, hvorfra der kan hentes in- 
spiration og hvor der foreligger omfattende forskning og dokumentation. Der er dog tale om erfaringer, som $i$ et vist omfang må tilpasses danske værdier og uddannelsesforståelser, men det er min opfattelse, at vi langt hen ad vejen kan bruge erfaringerne herfra til at håndtere nogle af de aktuelle udfordringer for dansk universitetsuddannelse og undervisning.

Intentionen med artiklen er overvejende at påpege de komplicerede forhold og efterfølgende opridse en strategi for, hvorledes man konkret kan håndtere underviserkvalificering i den komplicerede virkelighed, med eksemplet Adjunktpædagogikum. Dette forløb er udviklet med baggrund i den viden, der nationalt og internationalt eksisterer indenfor det universitetspædagogiske felt og organiseret, så den tager højde for adjunkters komplicerede hverdagspraksis på universitetet samt medgiver dem en bevidsthed om disse forhold, som baggrund for fortsat udvikling af deres egen undervisning.

\section{Indkredsning af en professionel strategi for universitetsundervisning}

»En professionel strategi for undervisning bør ses $i$ det samme lys som en professionel tilgang til jura, medicin eller ingeniørvirksomhed «(Ramsden, 1999, s. 21)

Ramsden sammenligner hermed det at arbejde professionelt som jurist, læge eller ingeniør med det at arbejde professionelt med uddannelse og undervisning. Dvs. at den professionelle udøvelse hviler på relevant teoretisk viden indenfor feltet samt systematisk udvikling af faglige og professionsrelevante kompetencer.

Den finske uddannelsesforsker Engeström har nogenlunde samme betragtninger, når han karakteriserer undervisning som »et alvorligt anliggende».

"The quality of instruction cannot be raised by odd tricks or by technical means alone. What is needed is theoretical insight into learning and teaching «. (Engeström 1994, s 1)

En bevidst professionel strategi for undervisningen er ifølge Engeström teoretisk indsigt i såvel undervisningssom læringspraksis.

At tale om en professionel strategi for undervisning ved universiteterne er dog efter nogle universitetsansattes mening at skyde over målet. Den holdning kan der være mange årsager til. En af dem er, at der blandt nogle universitetsundervisere er en forventning om, at studerende, der er nået til universitetsniveau, ikke behøver særlig pædagogisk support. Ikke desto mindre viser erfaringer fra udlandet, som de er dokumenteret i bl.a. Bowden og Marton (1998), Biggs (2003), Cowan
(1998), Ramsden (1999) og Hult (2001), at en professional strategi for kvalificering af opgaver, relateret til uddannelse og undervisning ofte har betydet, at undervisningen - og dermed de studerendes læringsudbytte potentielt blev forbedret, også blandt studentergrupper, der er præget af stor social og kulturel diversitet. En anden årsag er, som nævnt, at mange universitetsundervisere oplever, at det er vanskeligt at prioritere tid til udvikling af undervisningskompetencer, fordi de oplever så mange andre komplekse krav.

En professionel strategi for undervisningen indikerer imidlertid blot, at undervisningspraksis placeres $i$ en vidensbaseret kontekst, dvs. at ledere og undervisere besidder såvel teoretisk viden om undervisning og læreprocesser som evnen til, med udgangspunkt i reflekteret teoretisk viden, at træffe de nødvendige og relevante fagdidaktisk begrundede valg for den konkrete undervisning.

Karakteristisk for professionelle er ifølge Ramsden, at de er i besiddelse af teoretisk viden, som er relevant for professionen - og som repræsenterer en række teknikker, regler og metoder, en ordnet struktur af tanker og materialer. Den professionelle anvender disse som udgangspunkt for at træffe beslutninger om hensigtsmæssige fremgangsmåder for praksis, begrundet $\mathrm{i}$ mange forskellige metodemæssige valgmuligheder. Det er grundlaget for den måde, som mange akademikere handler på i deres professionelle arbejdsliv. Inden for undervisningsområdet eksisterer der et væld af undervisnings- og læringspraksisformer, hvis anvendelse hver især kan begrundes $\mathrm{i}$ bevidste fagdidaktiske analyser, eksempelvis analyser af undervisningens mål, fagets karakter og relevans og studerendes forudsætninger og ressourcer. Hos mange professionelle er der imidlertid ofte ikke tale om særlig høj bevidsthed om relationerne mellem teori og praksis, for underviseres vedkommende om relationerne mellem teorier om undervisning og undervisningens praksisformer. Eksempelvis refererer Schön (1987) til begrebet tavs viden, der karakteriserer en ofte for lille sammenhæng mellem teori (knowing that) og handling (knowing how). Praktikere er ifølge Schön i varierende grad $\mathrm{i}$ stand til at udtrykke deres teori. Han argumenterer imidlertid samtidig for, at knowing how ofte ikke lader sig udlede af knowing that. Hvorledes professionelle handler i praksis er således vanskeligt umiddelbart at udlede af teori. Derfor kan det være hensigtsmæssigt, at professionelle tilegner sig "redskaber« til at analysere og reflektere over forholdet teoripraksis. Den konkrete praktiske handling kalder Schön for handlingsteori. Oget bevidsthed om relationer mellem teori og praksis kan tilegnes i kvalificeringsforløb, hvor hovedsigtet er, at underviserne tilegner sig såvel viden om undervisning og læring som øget bevidsthed om relationen teori-praksis. Eksempelvis repræsenterer didaktik (teorien om undervisning) et redskab og en ramme for analyse af kontekstuelle og relationelle forhold i undervisningens teori og praksis. 
En professionel strategi for undervisning er især begrundet $i$, at det ikke fremover vil være tilstrækkeligt, at undervisere alene er dygtige på deres faglige og forskningsmæssige felt. Fagene er under indflydelse af den samfundsmæssige og videnskabelige udvikling. Det indebærer en fornyelse og omstilling, som undervisningen nødvendigvis må sikre, at studerende bevidstgøres om, hvis de som nyuddannede kandidater fra universiteterne skal kunne imødekomme forventningerne fra samfundet og fra arbejdspladserne. For at det kan lade sig gøre, vil det være nødvendigt, at underviserne hele tiden både er opdateret $\mathrm{i}$ forhold til udviklingen inden for deres faglige felt og er pædagogisk kvalificeret til at kunne designe undervisnings- og læringssituationer, der gør det muligt for studerende med forskellige forudsætninger og ressourcer at tilegne sig den nyeste viden og færdigheder inden for et givet uddannelsesfelt. Underviserne skal samtidig være i stand til at varetage de forskellige opgaver, der knytter sig til "underviserarbejdet«, dvs. udvikling og planlægning af uddannelser og undervisning, afvikling af undervisning, vejledning og evaluering, såvel individuelt som i samarbejde med kolleger og studerende - og ofte på tværs af faglige og institutionelle grænser.

Den professionelle autoritet hos en forsker ved universitetet hviler på et grundlag af stor viden inden for et eller flere forskningsfelter. Den professionelle autoritet hos forskeren som underviser og vejleder hviler i bedste fald på et grundlag af didaktisk reflekteret viden og erfaringer, dvs. viden om og erfaringer med, hvordan man bedst kan undervise i og lære de studerende et fag og dermed sikre sig, at de tilegner sig øvrige relevante kompetencer inden for faget og uddannelsen. Det er med andre ord ikke tilstrækkeligt at være fagligt og forskningsmæssigt velfunderet. Også kompetencer, der drejer sig om at være $i$ stand til at tolke mål for uddannelse og undervisning og på baggrund af didaktisk analyse omsætte disse til relevant og meningsfyldt undervisning af en given studentergruppe, præget af diversitet og mangfoldighed er nødvendige, hvis man fremover, som universitetsunderviser, skal kunne håndtere de forskellige opgaver i undervisningen

I diskussionen om professionalisering af 'underviserarbejdet' kan vi hente inspiration hos eksempelvis den norske uddannelsesforsker Dale (1999) og hos Stenhouse (1975). Ifølge de to forskere er det ikke tilstrækkeligt, at en undervisers arbejde alene bliver vurderet af andre. Underviseren har derimod også brug for at studere sig selv. De to forskere knytter underviserens professionalitet sammen med et forpligtende engagement og dygtighed $i$ at studere sin egen undervisningspraksis jf. også Ramsden (1999). Stenhouses perspektiv på pædagogisk professionalitet er refleksivitet, dvs. systematisk og kritisk gennemgang af egne handlinger i forhold til undervisningsmæssige opgaver. Professionalitet $i$ undervisningsmæssige opgaver er, at underviseren tilegner sig strukturer og sprog (i.e. begreber og teorier) til at beskrive, fortolke, analysere og vurdere en given læreplan (f.eks. en studieordning), undervisning og studerendes læreprocesser. Professionalitet i varetagelsen af undervisning udvikles dermed ved, at praktiske løsninger gradvist udvikles i takt med, at underviseren kontinuerligt gennemfører selvevalueringer. Jeg vender sidst i artiklen tilbage til, hvorledes disse tanker er forsøgt indlejret $\mathrm{i}$ underviserkvalificeringsstrategien for adjunkter på Aalborg Universitet. Inden jeg når dertil, vil jeg gennemgå de politiske beslutninger, der allerede præger vilkårene for bl.a. varetagelse af undervisningen ved universiteterne.

\section{Udfordringer for universitetsundervisning $i$ en aktuel kontekst}

Det universitetspædagogiske felt er bredt og dynamisk, idet det relaterer sig til praksis i uddannelsessystemer med opgaver, der skal tilgodese en række forskellige interesser relateret til forskning, til generel samfundsmæssig dannelse og uddannelse og til erhvervslivet/ arbejdsmarkedet. Det er bredt, fordi universitetet har til opgave at uddanne kandidater til såvel forskersamfundet som til samfundet generelt. Det er dynamisk, fordi uddannelsessystemet løbende må forholde sig til og udvikle undervisningsaktiviteter i relation til udviklingen i samfundet og på det specifikke akademiske arbejdsmarked. Uddannelserne er derfor hele tiden underlagt forskellige skiftende krav og forventninger fra samfundet og fra det politiske system.

I det universitetspædagogiske felt skal man altså forholde sig til uddannelse og undervisning i forhold til et samfund og et arbejdsmarked, der er under stadig forandring. De studerende skal udvikle akademisk faglige og personlige kompetencer til at kunne agere $\mathrm{i}$ et samfund, som vi endnu kun kan gisne om. (Bowden og Marton, 1998) udtrykker det således,

"The kind of learning we are interested in is learning which implies that the learners develop capabilities for seeing or experiencing situations or phenomena in certain ways ........ Students can therefore be prepared for the unknown variation among situations in the future through experiencing variation in their education, which will enable them to discern critical aspects of novel situations" (Bowden og Marton, 1998, s. 24).

Universitetspædagogik må derfor forstås og forklares med udgangspunkt i en bestemt historisk periode (Engeström, 1994), hvor generelle samfundsmæssige træk vil præge universiteternes rolle og funktioner. Den globaliseringsproces, som også universiteterne er omfattet af, får uomtvisteligt afgørende betydning for håndteringen af uddannelserne og undervisningen, jf. eksempelvis udmeldinger fra VTU (2006), Globaliseringsrådet (2006) OECD (2004). Der er tale om udmeldinger, der 
givetvis bliver konfronteret med meninger og holdninger blandt universitetsansatte forskere/undervisere, begrundet i de strukturer og traditioner, der har været fremherskende $i$ universitetssystemet gennem mange år og derfor vil få mange forskellige udtryksformer, fra modstand til at kunne se nye muligheder.

Der er tale om udviklingstendenser, som foregår internationalt. På europæisk plan er universiteternes fremtidige samfundsmæssige rolle blevet ny-tolket ved en række politiske beslutningsprocesser i slutningen af 90'erne. Bologna-deklarationen fra juni 1999, som blev underskrevet af ministre fra 40 europæiske lande, er blevet en vigtig strukturel ramme om det europæiske uddannelsessamarbejde. Den indledte en proces, der løber frem til år 2010, hvor målet bl.a. er at gøre de europæiske udannelsessystemer mere transparante, at sætte kvalitetssikring i højsædet og at sikre, at de studerendes mobilitet øges.

To andre europæiske initiativer har betydning for universiteterne. Det ene er Lisssabon-konventionen (1998) om "Anerkendelse af kvalifikationer inden for de videregående uddannelser i Europaregionen". Det andet initiativ er Barcelona-deklarationen, hvor EU's stats- og regeringschefer i Barcelona i 2002 aftalte, at Europa skal gøres til den mest konkurrencedygtige og dynamiske vidensbaserede økonomi i verden. Barcelona-deklarationen understreger universiteternes rolle som forskningsbærende institutioner (Rektorkollegiet, 2004). I den forbindelse redegøres der bl.a. for universiteternes stigende rolle $\mathrm{i}$ innovationsprocessen, deres bidrag til økonomisk konkurrenceevne og samfundsmæssig sammenhæng, herunder deres rolle i lokalsamfundets og regionens liv. I en opfølgende meddelelse fra Europakommissionen (2003) karakteriseres universiteterne som "the heart of the Europe of knowledge ". Der er ingen tvivl om, at disse politiske krav og strategier făr betydning for de universitetsansattes hverdag, både hvad angår forventninger til forskningens og til undervisningens kvantitet og kvalitet. Det er i dette internationale politiske krydsfelt, en strategi for professionalisering af undervisningsarbejdet ved universiteter også må ses.

Det skal i den sammenhæng nævnes, at de europæiske universiteter $i$ et par århundreder har været præget af den model, som blev udviklet af Humboldt, hvor forskningen er "the heart of the university activity" (Wittrock,1997). Den model vil fortsat udgøre basis for undervisningen. I dag skal universiteterne imidlertid samtidig forholde sig til en stadig større efterspørgsel efter akademiske uddannelser samt indgå i innovative og anvendelsesorienterede aktiviteter på forskningsområdet.

Denne tendens vil fortsætte i mange år, begrundet i stigende antal studerende og som følge af behov for fortsat uddannelse hos store dele af befolkningen, jf. eksempelvis strategien om livslang læring, som den bl.a. er formuleret i Bologna deklarationen. I den sammenhæng må der ikke på nogen måde gåes på kompromis med kvaliteten af hverken forskningen eller undervisningen,

»It is crucially important to maintain and strengthen the excellence of teaching and research, without compromising the level of quality offered, while still ensuring broad fair and democratic access" (Commission of the European Communities, 2003 s. 6)

Det hører ikke hjemme i denne artikel at komme med løsninger på, hvorledes forventningerne til fulde kan indfries. Formålet er alene at skitsere et bud på, hvorledes yngre undervisere kan kvalificere sig til at håndtere fremtidige udfordringer på uddannelsesområdet.

\section{Potentialer for en professionel strategi for undervisningen ved Aalborg Universitet}

Adjunktpædagogikum ved Aalborg Universitet er udviklet under hensyntagen til den særlige kontekst, der karakteriserer netop dette universitet med dets særlige pædagogiske form, det problemorienterede projektarbejde. Der har siden universitetets etablering i 1974 været fokus på undervisning og læring. Det betyder, at mange undervisere og vejledere ved Aalborg Universitet har nogle særlige forudsætninger for at deltage i undervisningskvalificerende forløb, fordi undervisningsformerne bliver diskuteret, der bliver taget stilling til, hvornår de studerende skal lære noget ved projektarbejdsformen og hvornår det er nødvendigt at anvende andre undervisningsformer. Projektarbejdsformen er blot én af de undervisnings-/organiseringsformer, der benyttes. Den indeholder dog mange af de kvaliteter, der også ses fremhævet i forbindelse med den internationale 'peer learning' strategi (Boud, 2001), hvor der ligeledes er tale om organiserede samarbejdsformer blandt de studerende. Projektarbejdsformens styrke er, at den potentielt tilgodeser krav om faglig fordybelse og udvikling af analytiske og metodiske kvalifikationer og kompetencer hos studerende. Den giver samtidig mulighed for, at der arbejdes med deltagerstyrede processer, som kan være enten problem- eller disciplinorienterede. Projektarbejdsformen placerer sig inden for Problem Based Learning traditionen (PBL). PBL er et princip, som indikerer anvendelse af mange forskellige undervisningsformer, hvor studerendes problemorienterede og undersøgende tilgang står centralt. Der kan være tale om mere eller mindre underviserstyrede læringsaktiviteter, men kendetegnende for projektarbejdsformen ved Aalborg Universitet er, at de studerende under studiet er i tæt dialog med universitetets vejledere, hvilket selvsagt kræver nogle særlige evner hos underviserne i vejlederfunktionen for at kunne håndtere deres rolle i samarbejdsprocessen under hele projektforløbet. 
Arbejdsprocessen og læringen i den problemorienterede projektorganiserede undervisningsform har samtidig mange ligheder med arbejds- og læreprocesser inden for visse typer af forskningsarbejde og med typer af arbejdsprocesser, som foregår på akademiske arbejdspladser med projektledelse og udviklingsarbejde. De studerende er i vidt omfang selv med til, inden for uddannelsesbestemte rammer, at definere de opgaver og problemstillinger, som de skal arbejde med, hvilket giver dem en særlig motivation for at arbejde med fagene. I den sammenhæng kan studerendes arbejde på specielt de sidste årgange sammenlignes med forskning indenfor principper om den s.k. modus 2 forskning (Gibbons, 1994 og Wenneberg, 2000), hvor hovedvægten er på bl.a. vidensanvendelse. Der er således mange lighedspunkter i de læreprocesser, som hhv. underviserne og de studerende befinder sig i - og dermed gode muligheder for at designe undervisningsforløb, hvor læring og udbytte er i fokus hos såvel underviserne som hos de studerende, dvs. øge bevidstheden om relationerne mellem viden om undervisning, læring og praksis.

Undervisningens vigtigste funktion er at bidrage til, at studerende tilegner sig viden, som er ny for dem. Forskning handler ligeledes om udvikling af ny viden, som er ny i absolut forstand, dvs. at ingen andre tidligere har udviklet den (Bowden og Marton, 1998). Der kan ifølge de to forskere tales om to former for vidensformation, 1) læring på det individuelle plan, dvs. typisk den individuelle studerendes læring (på Aalborg Universitet vil der qua projektarbejdsformen ofte være tale om studerendes individuelle læring gennem kollektive læreprocesser) og 2) læring på det kollektive plan, dvs. den viden, som produceres af forskerne $\mathrm{i}$ forskningsprocessen. Forfatterne mener, at det er interessant at kigge på relationen mellem de to former for vidensformation, i stedet for alene at fokusere på relationen mellem undervisning og forskning. De studerendes læring er ikke alene en funktion af undervisning, de studerende tilegner sig viden via forskellige metoder - og undervisning er blot en af disse metoder. De studerende tilegner sig viden og nye forståelser med udgangspunkt $\mathrm{i}$ forskellige aktiviteter på et studium: Forelæsninger, seminarer, workshops, hjemmearbejde, projektarbejde osv. At udvikle helt ny viden, som forskerne gør det, er en stor læringserfaring for dem, der er involveret i processen. En hensigtsmæssig tilgang til undervisning af studerende kunne for universitetsansatte undervisere og forskere være at se tilbage på den ofte vanskelige læreproces, de selv indgår $i$, når de er i en forskningsproces. Der er m.a.o. potentialer $i$ at sætte fokus på det, der kunne være fælles for såvel universitetsansatte undervisere som studerende, idet de hver i sær over tid ofte befinder sig i udfordrende læreprocesser.

\section{Case: Adjunktpædagogikum}

Adjunktpædagogikum har som et centralt mål, at adjunkterne gennem forløbet opnår klarhed over de forskellige roller og krav, der stilles til dem som forskere og undervisere ved universitetet og over deres ressourcer og potentialer for at varetage opgaverne professionelt.

Adjunkter skal for at begå sig i universitetets karrieresystem inden for en tre-års periode kvalificere sig både inden for forskningen $o g$ inden for undervisning og vejledning. Derfor er der i adjunktpædagogikumforløb tilstræbt en tankegang og en struktur, der gør det muligt for adjunkterne at forene de forskellige krav og vilkår for deres deltagelse. Forløbet, der varer 14 måneder, er fleksibelt og koblet til den individuelle adjunkts undervisnings- og vejledningspraksis.

Adjunkternes tilegnelse af viden om undervisning og læring og kvalificeringsprocessen foregår således med afsæt $\mathrm{i}$ eget undervisningsområde og tidligere erfaringer, dvs. med afsæt i det specifikke fagdidaktiske og undervisningsmæssige felt. Målet er, at deltagerne udvikler sig til teoretisk reflekterende undervisnings- og vejledningspraktikere, der med baggrund i fagdidaktisk analyse og refleksion får erfaringer med at anvende differentierede undervisnings- og læringsformer, der hjælper de studerende til at tilegne sig relevante faglige og akademiske kompetencer. Målene er bredt definerede ud fra en erkendelse af, at adjunkternes forforståelse og anvendelse af det undervisnings- og læringsteoretiske begrebsapparat varierer meget. Deltagerne starter og slutter derfor på forskellige niveauer. Hovedsigtet er, at den enkelte gennemgår en udviklingsproces, hvor undervisnings- og vejledingsmæssige kompetencer videreudvikles og forbedres på et bevidst fagligt og reflektorisk niveau.

Med inspiration fra Schöns tilgang om den reflekterende praktiker (Schön, 1987) tilstræbes det, at deltagerne igennem forløbets 14 måneder tilegner sig øget bevidsthed om forholdet mellem espoused theory (teorier om undervisning og læring, som vi kender og kan redegøre for) og knowing how (praktisk handling $\mathrm{i}$ undervisning og vejledning). Ifølge Schön kan praktisk handling ofte ikke udledes direkte af teori. Det didaktiske begrebsapparat og undervisningsportfoliometodikken (Tenhula 1996, Seldin 1997, Dysthe, 1999 og Baume, 2002) anvendes derfor gennem kurset som redskaber til at analysere, reflektere og dokumentere relationerne mellem teori og praktisk handling. Det didaktiske begrebsapparat, som adjunkterne introduceres til, angiver en bred tilgang til didaktik, med hvilket det er muligt at analysere såvel kontekstuelle forhold, fx aktuel universitetspolitik, økonomi og organisation, som andre forhold, der er i spil i og påvirker undervisnings- og vejledingssituationen, fx mål (kompetencer), studerendes forudsætninger og læringsstrategier samt undervisningens resultater.

I tilrettelæggelsen af adjunktpædagogikum forsøger 
vi at demonstrere, at det er muligt at designe og gennemføre uddannelse i en kompleks kontekst, hvor målgruppen er præget af stor faglig og kulturel diversitet og hvor kravene til undervisningen skifter. Med udgangspunkt $i$ universitetspædagogisk og didaktisk analyse inddrages de forandringer, der løbende forekommer, når undervisningen i praksis skal afvikles. Adjunkterne kommer fra forskellige hovedområder: naturvidenskab, ingeniørvidenskab, humaniora og samfundsvidenskab. En grundlæggende præmis er dermed deltagernes meget forskellige uddannelsesmæssige og faglige baggrunde, praksiserfaringer, forudsætninger og traditioner for at beskæftige sig med universitetspædagogiske problemstillinger. Nogle adjunkter vil via deres faglige og forskningsmæssige baggrund være bekendte med - eller ligefrem besidde forskningsbaseret viden inden for det pædagogiske og læringsmæssige felt, mens det for andre ikke ligger lige for at skulle beskæftige sig med universitetspædagogiske spørgsmål ud fra en undervisnings- og læringsteoretisk tilgang. Dette er en virkelighed, der har præget adjunktpædagogikum i alle årene - men som imidlertid også er et vilkår for adjunkternes egen undervisning og vejledning, hvor kulturel og social diversitet blandt målgrupper $\mathrm{i}$ dag mere er reglen end undtagelsen. Det er intentionen, at strukturen og pædagogikken i adjunktpædagogikum på eksemplarisk vis giver mulighed for at arbejde på forskellige niveauer og ud fra forskellige forudsætninger. Fælles for alle adjunkterne er, at de underviser og vejleder i uddannelsesmiljøer, hvor den problemorienterede projektarbejdsform er dominerende. Som udgangspunkt har de altså en vis fælles praksiserfaringsbaggrund.

De forhold, der har betydning for adjunkternes deltagelse $i$ et underviserkvalificeringsforløb, dvs. deres forskellige baggrunde, deres oplevelse af pres, modstand, manglende tid er også medtænkt i organiseringen af forløbet. Adjunkterne møder således en variation af undervisnings- og organiseringsformer, spændende over præsentationer, workshops, undervisningsportfoliometodik, selvstudium, studiegrupper, supervision og vejledning samt en udstrakt grad af styring og kommunikation via internettet og detaljerede skriftlige vejledninger (Adjunktpædagogikum 2005-2007).

Ved den pædagogiske tilrettelæggelse er der hentet teoretisk inspiration fra eksempelvis mesterlæretraditionen (Wenger, 1999), fra teorien om nærmeste udviklingszone (Vygotsky, 1978) og om ekspansiv læring (Engeström, 1987) samt i læringsmæssige og vejledningsmæssige erfaringer, som uddannelsesforskerne Lycke, Lauvås og Handal (1996, 1997, 2001) har opnået og dokumenteret i deres forskning ved Oslo Universitet. Herudover er der hentet inspiration i erfaringer fra udlandet, Gibbs, (2002), Biggs, (2003), Cowan, (1998), Boud, (2001) og Ramsden (1999).

I det folgende vil nogle af elementerne i adjunktpædagogikum blive gennemgået.

\section{Undervisningsportfolio}

Fokus gennem hele adjunktpædagogikum er, som anført, adjunktens videns- og erfaringsmæssige udgangspunkt for at arbejde med teorier om og af undervisnings- og læringspraksis. Med anvendelsen af portfolio-metodikken arbejder adjunkterne under hele forløbet systematisk med at beskrive egne forudsætninger og holdninger til undervisning og studerende samt egne forforståelser af undervisning og læring. Undervisningsportfolioen fungerer dermed som et redskab til systematisk dokumentation og refleksion af bestræbelserne på at blive mere teoretisk reflekterende undervisnings- og projektvejledningspraktikere. Med udgangspunkt i tidligere erfaringer og forforståelser inddrager de igennem forløbet nyere teorier og praksiserfaringer i refleksionerne. Teorier om undervisning og læreprocesser inddrages, når deltageren oplever dem som relevante og de kan inspirere til at forstå undervisnings- og vejledningspraksis ud fra nyvinkler.

\section{Studiegrupper}

En stor del af adjunkternes videnstilegnelse sker ved fælles læsning af udvalgt teoretisk materiale i studiegrupper og diskussioner af den enkelte adjunkts personlige interesser og mål, som de er formuleret i deres undervisningsportfolios og pædagogiske handlingsplaner. Den læste teori danner baggrund for refleksioner af praksis og udviklingsmuligheder.

\section{Supervision og vejledning}

Supervision og vejledning af adjunkterne indgår som væsentlige elementer. Hver adjunkt tildeles 2 vejledere, en fra adjunktens faglige miljø og en, der repræsenterer den universitetspædagogiske vinkel. I et vist omfang foregår der samtidig kollegasupervision mellem adjunkterne indbyrdes. Der er således etableret mulighed for, at læring og udvikling kan ske gennem handling i en konkret undervisnings- eller projektvejledningspraksis og i interaktion med vejledere og adjunktkolleger (peer-learning).

\section{Seminarer og workshops}

Undervejs i forløbet udbydes en række seminarer og workshops, der har fokus på centrale temaer og begreber inden for universitetspædagogisk teori og praksis og som har til formål overvejende at inspirere og bidrage yderligere til adjunkternes eget arbejde med at blive klogere på undervisning og vejledning.

I forhold til de seneste kursusforløb giver deltagerne udtryk for, at arbejdet med undervisningsportfolios, supervision og vejledning og i et vist omfang studiegrupper opleves som de aktiviteter, der har givet mest udbytte og størst tilfredshed. Den store udfordring er 
at få workshops til at matche adjunkturernes forskellige interesser og behov på det rette tidspunkt.

\section{Muligheder og motivation}

En grundlæggende præmis for hele forløbet er den enkelte adjunkts præferencer, muligheder og ønsker om at videreudvikle sin undervisnings- og projektvejledningspraksis. Dette giver nogle enestående muligheder for at beskæftige sig med det, som man er mest optaget af $i$ sin undervisnings- og vejledningspraksis. Igennem årene har mange adjunkter da også i forbindelse med evalueringer og gennem dokumentation $\mathrm{i}$ undervisningsportfolios givet udtryk for at have tilegnet sig viden og erfaringer, som de vurderer, de kan drage nytte af $i$ den fremtidige praksis. Nogle er endog blevet så optaget af området, at de har fået lyst til at arbejde meget mere med undervisningsspørgsmål. Andre har ment, at de fik mindre ud af kursets teoretiske del og at deres primære ønske var at få nogle flere værktøjer til den praktiske del af deres undervisning. Generelt er erfaringerne, at hvis adjunkter skal opleve stort udbytte og tilfredshed, skal de for det forste være i besiddelse af en vis grad af motivation og ønske om at arbejde med undervisningen, og for det andet skal de opleve støtte og opbakning til at fokusere på undervisningsarbejdet i deres faglige miljø. Som udgangspunkt har næsten alle deltagere et ønske om at forbedre deres muligheder for at gennemføre god undervisning. Det kan dog undertiden være vanskeligt at fastholde motivationen og ønsket, hvis der ikke i det faglige miljø eller i uddannelsernes tilrettelæggelse afsættes den nødvendige tid til kvalificering - og hvis underviserkvalificering skal konkurrere for meget med forskerkvalificering. Udfordringen for os som kursusudbydere er derfor hele tiden at videreudvikle forløbet på baggrund af de tilbagemeldinger, der kommer og at organisere det, så det både imødekommer, udfordrer og understøtter adjunkternes ønsker, behov og muligheder.

\section{Referencer}

Adjunktpædagogikum 2005-2007, www.puc.aau.dk

Argyris, C. (1991). Teaching Smart People How to Learn. Harvard Business Review, maj 1991.

Baume, D. \&Y. Mantz (2002). The Reliability of Assessment by Portfolio on a Course to Develop and Accredit Teachers in Higher Education. Studies in Higher Education Practice, The Open University, UK.

Biggs, J. (2003). Teaching for Quality Learning at University. The Society for Research into Higher Education.

Bologna Deklarationen (1999). www.bologna.dk.

Boud, D. (2001). Introduction: making the move to peer learning, i Boud, D., R. Cohen \& J. Simpson (eds). Peer Learning in higher education - learning from and with each other. London: Kogan Page.

Bowden J. \& F. Marton (1998). The University of Learning. London: Kogan Page.

Commission of the European Communities, Brussels, (2003). Communication from the Commission. The role of the universities in the Europe of Knowledge.
European Commission, Communication »Making an European area of lifelong learning a reality", COM (2001) 678 of 21.10.2001.

Cowan, J. (1998). On Becoming an Innovative University Teacher. Reflection in Action. The Society for Research into Higher Education.

Dale, E. L. (1999). Kundskab, Rationalitet og Didaktik, i Dale, E.L. (red.), Padagogisk Filosofi. Aarhus: Klim.

Dale, E. L. (1998). Padagogik og professionalitet. Aarhus: Klim.

Dysthe, O. (1999). Undervisning i høgare utdanning - like viktig som forskning? Undervisningsportefølgje som reiskap for å vurdere og utvikle lærardugleik. Norsk Pedagogisk Tidsskrift, 2, 1999.

Engeström Y. (1994), Training for change: New approach to instruction and learning in working life. International Labour Office.

Engeström Y. (1987); Learning by expanding: An activity-theoretical approach to developmental research. Helsinki: Orienta-Kunsultit.

European Commission, Joint Research Centre. Report on "The future of education between now and 2010", June 1999.

Gibbons, M. et al. (1994). The New Production of Knowledge. The Dynamics of Science and Research in Contemporary Societies. London: Sage.

Gibbs, G. (2002), Ten Years of Improving Student Learning, i Rust C. (ed.) Improving Student Learning Theory and Practice -10 Years On..The Oxford Centre for Staff and Learning Development. Proceedings of the $200210^{\text {th }}$ International Symposium.

Hult. H. (2001). Universitetsunderviseren $i$ det 21. arrhundredes videnssamfund. Oplæg på DUN-konference, Vingstedcentret, Vejle.

Krogh, L. (2005) (red.). Adjunktpadagogikum 2005-2007. (Kommenteret materialesamling). Aalborg: Pædagogisk Udviklingscenter.

Lauvås P. og Rump, C. (2001). Vor falles viden - kollegavejledning som metode til udvikling af undervisning ved højere lareanstalter. København: Samfundslitteratur.

Lauvås, P. og Handal, G. (1997). Vejledning og praktisk fagteori. Aarhus: Klim.

Lauvås, P., Lycke K.P. og Handal, G. (1996). Kollegavejledning i skolen. Peedagogik til tiden. Aarhus: Klim.

Ministeriet for Videnskab, Teknologi og Udvikling (febr. 2006). Kvalitet $i$ undervisningen.

OECD (2004), Evaluering af det danske Universitetssystem. Resumé og anbefalinger. Igangværende initiativer fra Ministeriet for Videnskab, Teknologi og Udvikling. Ministeriets hjemmeside.

Ramsden, P. (1999). Strategier for bedre undervisning. København: Gyldendal.

Rektorkollegiet (2004). Internationalisering af de danske universiteter. Vilkair og virkemidler. http://www.rektorkollegiet.dk/politik_debat/ publikationer/danske_publikationer/

Seldin, P. (1991). The Teaching Portfolio. Bolton: MA Anker Publiching.

Schön, D. (1987. The Reflective Practitioner. San Francisco: JosseyBass.

Stenhouse, L. (1975). An Introduction to Curriculum Research and Development. Heinemann London.

Tenhula, T. (1996). Improving Academic Teaching Practices by Using Teaching Portfolio - The Finish Way to do it. Paper. ICED Conference 1996. Preparing University Teaching.

Vygotsky, L.S. (1978). Mind in Society. The Development of Higher Psychological Process. Cambridge, Mass.: Harvard University Press

Wenger, E. (1999). Communities of Practice. Cambridge: Cambridge University Press.

Wenneberg, S. (2000). Forskningsledelse som arketypisk eksempel på vidensledelse - hvordan håndteres den anvendte faglighed? i Christensen, P. H.(red.) Viden om ledelse, viden om virksomheden. København: Samfundslitteratur.

Wittrock, Bjørn, (1997). Det moderne universitets forvandlinger. I Rasmussen, P. og A. Jacobsen (red.). Universiteter i dag. Politikkultur-ledelse. København: Samfundslitteratur. 